\title{
Scaling-up From Leaf to Whole-plant Level for Water Use Efficiency Estimates Based on Stomatal and Mesophyll Behavior
}

\section{Yonge Zhang}

China Institute of Water Resources and Hydropower Research

\section{Guodong Jia}

Beijing Forestry University

Chen Lihua

Beijing Forestry University

Xinxiao Yu ( $\nabla$ yuxinxia01111@126.com )

Beijing Forestry University https://orcid.org/0000-0003-1260-5712

\section{Research Article}

Keywords: mesophyll conductance, stomatal conductance, scaled-up, water use efficiency, whole-plant

Posted Date: September 13th, 2021

DOI: https://doi.org/10.21203/rs.3.rs-846919/v1

License: (9) This work is licensed under a Creative Commons Attribution 4.0 International License. Read Full License 
1 Scaling-up from leaf to whole-plant level for water use efficiency estimates based on stomatal and

2 mesophyll behavior

Yonge Zhang ${ }^{\mathrm{a}}$, Guodong Jia ${ }^{\mathrm{b}}$, Lihua, Chen ${ }^{\mathrm{b}}$, Xinxiao $\mathrm{Yu}^{\mathrm{b}}$

anstitute of Sediment Research, China Institute of Water Resources and Hydropower Research, Beijing 100038, China

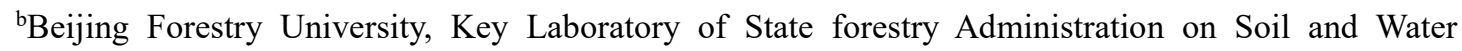
Conservation, 100083, Beijing, China

\section{Abstract}

Aims Prediction of whole-plant short-term water use efficiency (WUE $E_{\mathrm{s}, \mathrm{P}}$ ) is essential to indicate plant performance and facilitates comparison across different temporal and spatial scales. Here, the isotope model for $\mathrm{WUE}_{\mathrm{s}, \mathrm{P}}$ was scaled-up from the leaf to the whole-plant level.

Methods For $\mathrm{WUE}_{\mathrm{s}, \mathrm{P}}$ modelling, leaf gas exchange information, plant respiration and "unproductive" water loss were taken into account. Specifically, in shaping the expression of the $\mathrm{WUE}_{\mathrm{s}, \mathrm{P}}$, we emphasized the role of both stomatal $\left(g_{\mathrm{sw}}\right)$ and mesophyll conductance $\left(g_{\mathrm{m}}\right)$.

Results The verification showed that estimates of $g_{\mathrm{sw}}$ from the coupled photosynthesis $\left(P_{\mathrm{n}, \mathrm{L}}\right)-g_{\mathrm{sw}}$ model accounting for the effect of soil water stress slightly outperformed the model neglecting the soil water status effect, and the established coupled $P_{\mathrm{n}, \mathrm{L}}-g_{\mathrm{m}}$ model proved more effective in the estimation of $g_{\mathrm{m}}$ than the previously proposed model. Introducing the two diffusion control functions into the whole-plant model, the developed model for $\mathrm{WUE}_{\mathrm{s}, \mathrm{P}}$ effectively captured its response pattern to different $\mathrm{CO}_{2}$ concentration $\left(C_{\mathrm{a}}\right)$ and soil water content $(\mathrm{SWC})$ conditions.

Conclusions Overall, this study confirmed that accurate estimation of $\mathrm{WUE}_{\mathrm{s}, \mathrm{P}}$ requires an improved predictive accuracy of $g_{\mathrm{sw}}$ and $g_{\mathrm{m}}$. These results have important implications for predicting how plants 
respond to climate change.

Keywords: mesophyll conductance, stomatal conductance, scaled-up, water use efficiency, whole-plant level.

\section{Introduction}

The ratio of carbon assimilation to water loss, water use efficiency (WUE), is essential to optimize plant water use (Medrano et al., 2015) and can be defined at different temporal and spatial scales. At the leaf level, WUE describes the leaf net photosynthetic rate $\left(P_{\mathrm{n}, \mathrm{L}}\right)$ relative to the leaf transpiration rate $\left(E_{\mathrm{L}}\right)$.

Both processes are controlled by stomatal conductance $\left(g_{\mathrm{sw}}\right)$. The $P_{\mathrm{n}, \mathrm{L}}$ is also controlled by mesophyll conductance $\left(g_{\mathrm{m}}\right)$, in addition to $g_{\mathrm{sw}}$, as recent studies demonstrated that mesophyll resistance is not negligible (Flexas et al., 2006; Warren and Adams, 2006) and may be as important as stomatal conductance (Pérez-Martín et al., 2009). At the whole-plant level, although all photosynthetic and nonphotosynthetic parts contribute to respiration and water loss, the canopy accounts for the largest part of carbon assimilation and transpiration water loss. Therefore, changes in $g_{\mathrm{sw}}$ (and or $g_{\mathrm{m}}$ ) may result in a decrease or increase in whole-plant WUE, especially at smaller temporal scales.

Investigating whole-plant WUE at smaller temporal scales not only facilitates our understanding of whole-plant long-term WUE and the underlying mechanism, but also allows us to compare across different temporal and spatial scales. There have, however, been a few attempts to relate $g_{\text {sw }}\left(\right.$ and or $\left.g_{\mathrm{m}}\right)$ to whole-plant WUE at smaller temporal scales, or models to predict response pattern of whole-plant short-term WUE $\left(\mathrm{WUE}_{\mathrm{s}, \mathrm{P}}\right)$ to environmental changes. Estimation of $\mathrm{WUE}_{\mathrm{s}, \mathrm{P}}$ is frequently conducted on the assumption that leaf short-term WUE $\left(\mathrm{WUE}_{\mathrm{s}, \mathrm{L}}\right)$ is representative of $\mathrm{WUE}_{\mathrm{s}, \mathrm{P}}(\mathrm{Hu}$ et al., 2010). However, there may be a gap between daily integrals of leaf and whole-plant WUE, as carbon and water loss from non-photosynthetic tissue can result in a decrease in $\mathrm{WUE}_{\mathrm{s}, \mathrm{P}}$ whilst not affecting WUE $\mathrm{E}_{\mathrm{s}-\mathrm{L}}$. 
Therefore, it is critical to obtain adequate predictions of whole-plant WUE at smaller temporal scales.

It has been suggested that the leaf WUE model can be scaled to the whole-plant level by taking into account "unproductive" water loss and carbon use by respiration, independent of photosynthesis (Farquhar and Richards, 1984; Farquhar et al., 1989; Hubick and Farquhar, 1989). Built upon this concept, the Farquhar et al. (1989) model relates leaf gas exchange properties and carbon discrimination to wholeplant WUE, while it ignores the effect of mesophyll resistance (the inverse of $g_{\mathrm{m}}$ ) on carbon discrimination $(\Delta)$. It has been pointed out that the contribution of $g_{\mathrm{m}}$ to $\Delta$ needs to be considered (Seibt et al., 2008), and consequently, $g_{\mathrm{m}}$ might have to be incorporated in the approach of Farquhar et al. (1989) to accurately predict whole-plant WUE. This hypothesis was supported by our recent findings (Zhang et al., 2019), which found that the whole-plant model emphasizing the role of $g_{\mathrm{m}}$ outperformed the Farquhar et al. (1989) model. Despite years of research, the three most widely used approaches for determining $g_{\mathrm{m}}$, based on the high number of gas exchange properties or measurements of gas exchange combined with chlorophyll fluorescence or carbon isotope discrimination (Pons et al., 2009), use complex parameters and are associated with complicated measurements. These drawbacks limit the easy determination of $g_{\mathrm{m}}$. In contrast, the soil water content and potential $g_{\mathrm{m}}$ (unstressed $g_{\mathrm{m}}, g_{\mathrm{m}, \mathrm{p}}$ ) dependent empirical model proposed by Keenan et al. (2010), can easily be used. Unfortunately, the model is still flawed in reflecting the influence of other environmental factors and gas exchange properties on $g_{\mathrm{m}}$. A practical and relatively simple representation of mesophyll behavior may lie at the heart of a valid and useful prediction of $\mathrm{WUE}_{\mathrm{s}, \mathrm{P}}$. Furthermore, the revised whole-plant model (Zhang et al., 2019) for $\mathrm{WUE}_{\mathrm{s}, \mathrm{P}}$ included the presence of $g_{\mathrm{sw}}$, in addition to $g_{\mathrm{m}}$, thereby representing the linkage between $\mathrm{WUE}_{\mathrm{s}, \mathrm{P}}$ and $g_{\mathrm{sw}}$. For representation of stomatal behavior, although several models have been proposed, including the simple coupled photosynthesis-stomatal conductance $\left(P_{\mathrm{n}, \mathrm{L}}-g_{\mathrm{sw}}\right)$ model and its modified versions, it 
remains unclear which one is the most useful approach. In general, the WUE model scaling from leaf to whole-plant level needs to be revised and improved based on well-modeled stomatal and mesophyll behavior.

In this study, we developed a model to estimate $g_{\mathrm{m}}$ based on the empirical relationship between $g_{\mathrm{m}}$ and $P_{\mathrm{n}, \mathrm{L}}$ (i.e., the coupled photosynthesis-mesophyll conductance model). The revised $g_{\mathrm{m}}$ model and the previously established $g_{\mathrm{sw}}$ model were then incorporated into the whole-plant WUE model to estimate $\mathrm{WUE}_{\mathrm{s}, \mathrm{P}}$. Measurements of whole-plant net $\mathrm{CO}_{2}$ gas exchange and transpiration were conducted concurrently, allowing us to calculate the actual $\mathrm{WUE}_{\mathrm{s}, \mathrm{P}}$ and to compare the measured results with simulations obtained from the developed whole-plant WUE model. Our aim was, first, to establish a reliable model for $g_{\mathrm{m}}$; second, to check the applicability of the whole-plant WUE model scaled from the leaf level, based on estimations of stomatal and mesophyll behavior.

\section{Theoretical background}

2.1 Coupled $g_{\mathrm{sw}}-P_{\mathrm{n}, \mathrm{L}}$ model

Previous studies found that leaf stomatal conductance $\left(g_{\mathrm{sw}}, \mathrm{mol} \mathrm{H}_{2} \mathrm{O} \cdot \mathrm{m}^{-2} \cdot \mathrm{s}^{-1}\right)$ is highly correlated with photosynthesis $\left(P_{\mathrm{n}, \mathrm{L}}, \mu \mathrm{mol} \cdot \mathrm{m}^{-2} \cdot \mathrm{s}^{-1}\right)$. Based on this, a series of models on the basis of the linear relationship between $g_{\mathrm{sw}}$ and $P_{\mathrm{n}, \mathrm{L}}$ has been proposed (Ball et al., 1987; Jarvis, 1976; Leuning et al., 1990). By incorporating the effect of leaf-to-air vapor pressure deficit (D), Leuning et al. (1995) established an alternative coupled $P_{\mathrm{n}, \mathrm{L}}-g_{\mathrm{sw}}$ model based on former studies:

$$
g_{\mathrm{sw}}=g_{0, \mathrm{sw}}+g_{1} P_{\mathrm{n}, \mathrm{L}} \frac{f(D)}{C_{\mathrm{s}}-\Gamma},
$$

where $g_{0, \mathrm{sw}}$ and $g_{1}$ are fitted parameters and $g_{0, \mathrm{sw}}$ is considered to represent the residual stomatal conductance $\left(\mathrm{mol} \mathrm{H} \mathrm{H}_{2} \mathrm{O} \cdot \mathrm{m}^{-2} \cdot \mathrm{s}^{-1}\right) ; C_{\mathrm{s}}$ is the leaf surface $\mathrm{CO}_{2}$ concentration $\left(\mu \mathrm{mol} \cdot \mathrm{mol}^{-1}\right) ; \Gamma$ is the $\mathrm{CO}_{2}$ compensation point $\left(\mu \mathrm{mol} \cdot \mathrm{mol}^{-1}\right) ; f(\mathrm{D})$ is the vapor pressure deficit-dependent function. To describe the 
effect of $D$ on stomatal behavior, numerous expressions have been introduced (Ball et al., 1987; Collatz et al., 1991; Leuning et al., 1995; Lloyd, 1991; Lohammer et al., 1980; Yu et al., 2001). Lloyd (1991) and $\mathrm{Yu}$ et al (2001) have consistently found that the precision of estimation was highest when imposing the function $f(\mathrm{D})=h_{\mathrm{s}}$, with $h_{\mathrm{s}}$ referring to relative humidity at leaf surface in $\%$. Thus, we adopted the expression $f(\mathrm{D})=h_{\mathrm{s}}$ in the Leuning et al. (1995) model.

The model introduced by Leuning et al. (1995) has been widely used to predict gas exchange properties at the leaf scale (Egea et al., 2011a; Yu et L., 2001), albeit without taking into account the response of water stress. To overcome this limitation, Egea et al. (2011b) proposed an improved model, which incorporated a soil water stress-dependent function, $f\left(\theta_{\mathrm{s}}\right)$, to describe the behavior of gas exchange properties:

$$
g_{\mathrm{sw}}=g_{0, \mathrm{sw}}+g_{1} P_{\mathrm{n}, \mathrm{L}} \frac{f\left(\theta_{\mathrm{s}}\right) f(D)}{C_{\mathrm{s}}-\Gamma}
$$

2.2 Coupled $g_{m}-P_{n}$ model

Models which can easily represent mesophyll behavior in response to environmental drivers are still scarce. Considering restrictions of soil water stress on $g_{\mathrm{m}}\left(\mathrm{mol} \mathrm{CO}_{2} \cdot \mathrm{m}^{-2} \cdot \mathrm{s}^{-1}\right)$, Keenan et al. (2010) proposed a function to predict the linkage between $g_{\mathrm{m}}$ and soil water status:

$$
g_{\mathrm{m}}=f\left(\theta_{\mathrm{m}}\right) g_{\mathrm{m}, \mathrm{p}}
$$

where $f\left(\theta_{\mathrm{m}}\right)$ is the mesophyll conductance limitation function, which depends on soil water stress; $g_{\mathrm{m}, \mathrm{p}}$ is the potential (unstressed) $g_{\mathrm{m}}$. This model has been used to represent the feedback of $g_{\mathrm{m}}$ to soil water stress (Egea et al., 2010b), but does not take into account the response of mesophyll behavior to other environmental drivers, such as $C_{\mathrm{a}}$. In fact, $g_{\mathrm{m}}$ is affected by increases or decreases in $C_{\mathrm{a}}$, and even changes more subtly with changes in $C_{\mathrm{a}}$ than in $g_{\mathrm{sc}}\left(g_{\mathrm{sc}}=g_{\mathrm{sw}} / 1.6\right)$ (Flexas et al., 2007). Previous studies have observed that the $P_{\mathrm{n}, \mathrm{L}}$ increased linearly with $g_{\mathrm{m}}$ (Douthe et al., 2012; Misson et al., 2010; Xu and Zhou, 
111

112

$119 f\left(\theta_{\mathrm{i}}\right)=\left\{\begin{array}{cc}1 & \theta \geq \theta_{\mathrm{c}} \\ {\left[\frac{\theta-\theta_{\mathrm{w}}}{\theta_{\mathrm{c}}-\theta_{\mathrm{w}}}\right]^{q_{\mathrm{i}}}} & \theta_{\mathrm{w}} \leq \theta \leq \theta_{\mathrm{c}}, \\ 0 & \theta \leq \theta_{\mathrm{w}}\end{array}\right.$

120 where $\theta$ is the actual soil water content (\%); $\theta_{\mathrm{c}}$ and $\theta_{\mathrm{w}}$ are soil water content levels at field capacity

$121(26.20 \%)$ and permanent wilting point (4.08\%), respectively; and the subscript $\mathrm{i}=\mathrm{s}$ and $\mathrm{m}$ represent stomatal and mesophyll limitations, respectively. In this study, the selected values for tunable parameters 1984):

$$
\mathrm{WUE}_{\mathrm{i}, \mathrm{L}}=\frac{P_{\mathrm{n}, \mathrm{L}}}{E_{\mathrm{L}}}=\frac{P_{\mathrm{n}, \mathrm{L}}}{g_{\mathrm{sw}} D}
$$


131

132

Eq. (6), we obtain the following formulas, respectively:

$$
\begin{aligned}
\mathrm{WUE}_{\mathrm{i}, \mathrm{L}} & =\frac{P_{\mathrm{n}, \mathrm{L}}}{D} \times \frac{C_{\mathrm{s}}-\Gamma}{\left(C_{\mathrm{s}}-\Gamma\right) g_{0, \mathrm{sw}}+g_{1} P_{\mathrm{n}, \mathrm{L}} f\left(\theta_{\mathrm{s}}\right) f(D)} \\
\mathrm{WUE}_{\mathrm{i}, \mathrm{L}} & =\frac{P_{\mathrm{n}, \mathrm{L}}}{D} \times \frac{C_{\mathrm{s}}-\Gamma}{\left(C_{\mathrm{s}}-\Gamma\right) g_{0, \mathrm{sw}}+g_{1} P_{\mathrm{n}, \mathrm{L}} f(D)}
\end{aligned}
$$

The WUE $\mathrm{i}_{\mathrm{L}, \mathrm{L}}$ inferred from Eq. (7) with well parameterized $q_{\mathrm{s}}\left(q_{\mathrm{s}}=0.25\right.$, see Results 3.1$)$ is model configuration 1, and that inferred from Eq. (8) is model configuration 2.

The whole-plant instantaneous water use efficiency $\left(\mathrm{WUE}_{\mathrm{i}, \mathrm{P}}, \mathrm{mmol} \cdot \mathrm{mol}^{-1}\right)$ is the ratio of wholeplant net photosynthetic rate $\left(P_{\mathrm{n}, \mathrm{p}}, \mu \mathrm{mol} \cdot \mathrm{h}^{-1}\right)$ to transpiration rate $\left(E_{\mathrm{p}}, \mathrm{mmol} \cdot \mathrm{h}^{-1}\right)$ (Farquhar et al., 1989). Considering respiration and water loss from non-photosynthetic organs, the ratio of instantaneous net photosynthesis to transpiration can be scaled from the leaf to the whole-plant level:

$$
\mathrm{WUE}_{\mathrm{i}, \mathrm{P}}=\frac{P_{\mathrm{n}, \mathrm{P}}}{E_{\mathrm{p}}}=\frac{P_{\mathrm{n}, \mathrm{L}}}{E_{\mathrm{L}}} \times \frac{\left(1-\phi_{\mathrm{c}, \mathrm{i}}\right)}{\left(1+\phi_{\mathrm{w}, \mathrm{i}}\right)}=\frac{P_{\mathrm{n}, \mathrm{L}}}{g_{\mathrm{sw}} D} \times \frac{\left(1-\phi_{\mathrm{c}, \mathrm{i}}\right)}{\left(1+\phi_{\mathrm{w}, \mathrm{i}}\right)},
$$

where $\phi_{\mathrm{c}, \mathrm{i}}\left(=\left(3.6 P_{\mathrm{n}, \mathrm{L}} \times L A-P_{\mathrm{n}, \mathrm{P}}\right) /\left(3.6 P_{\mathrm{n}, \mathrm{L}} \times L A\right)\right.$, with $L A$ referring to plant total leaf area in $\left.\mathrm{m}^{2}\right)$ is the proportion of respiration from non-photosynthetic parts (twigs and stem) during the daytime, and $\phi_{\mathrm{w}, \mathrm{i}}$ $\left(=\left(E_{\mathrm{P}}-3.6 E_{\mathrm{L}} \times L A\right) /\left(3.6 E_{\mathrm{L}} \times L A\right)\right)$ is the proportion of water loss from non-photosynthetic parts during the daytime. Similarly, we substituted the simulated $g_{\text {sw }}$, calculated via the Egea et al. (2011b) model (Eq. 2) and the Leuning et al. (1995) model (Eq. 1) into Eq. (9), obtaining the following formulas, respectively:

$$
\begin{aligned}
\mathrm{WUE}_{\mathrm{i}, \mathrm{P}} & =\frac{P_{\mathrm{n}, \mathrm{L}}}{D} \times \frac{C_{\mathrm{s}}-\Gamma}{\left(C_{\mathrm{s}}-\Gamma\right) g_{0, \mathrm{sw}}+g_{1} P_{\mathrm{n}, \mathrm{L}} f\left(\theta_{\mathrm{s}}\right) f(D)} \times \frac{\left(1-\phi_{\mathrm{c}, \mathrm{i}}\right)}{\left(1+\phi_{\mathrm{w}, \mathrm{i}}\right)} \\
\mathrm{WUE}_{\mathrm{i}, \mathrm{P}} & =\frac{P_{\mathrm{n}, \mathrm{L}}}{D} \times \frac{C_{\mathrm{s}}-\Gamma}{\left(C_{\mathrm{s}}-\Gamma\right) g_{0, \mathrm{sw}}+g_{1} P_{\mathrm{n}, \mathrm{L}} f(D)} \times \frac{\left(1-\phi_{\mathrm{c}, \mathrm{i}}\right)}{\left(1+\phi_{\mathrm{w}, \mathrm{i}}\right)}
\end{aligned}
$$

The WUE $\mathrm{W}_{\mathrm{i}, \mathrm{P}}$ inferred from Eq. (10) with the tunable parameter $q_{\mathrm{s}}=0.25$ is model configuration 1 , while that inferred from Eq. (11) is model configuration 2. 
151

152

153

$$
\frac{C_{\mathrm{i}}}{C_{\mathrm{a}}}=\frac{\Delta-a+\left(b-a_{\mathrm{m}}\right) \frac{g_{\mathrm{sw}}}{1.6 g_{\mathrm{m}}}}{b-a+\left(b-a_{\mathrm{m}}\right) \frac{g_{\mathrm{sw}}}{1.6 g_{\mathrm{m}}}}
$$


171

172

173

atmospheric $\mathrm{CO}_{2}$ and water-soluble organic materials (WSOM, fast-turn-over carbohydrates) in leaves, respectively.

Substituting Eq. (13) and Eq. (14) into Eq. (12), we obtain the following equation:

$$
\mathrm{WUE}_{\mathrm{s}, \mathrm{P}}=\frac{C_{\mathrm{a}}}{1.6 D} \times \frac{b-\Delta}{b-a+\left(b-a_{\mathrm{m}}\right) \frac{g_{\mathrm{sw}}}{g_{\mathrm{m}}}} \times \frac{\left(1-\phi_{\mathrm{c}, \mathrm{s}}\right)}{\left(1+\phi_{\mathrm{w}, \mathrm{s}}\right)}
$$

Similar to the simulation of WUE $E_{i, L}$, two model configurations were applied in Eq. (15), and we obtained the following equations:

$$
\mathrm{WUE}_{\mathrm{s}, \mathrm{P}}=\frac{C_{\mathrm{a}}}{1.6 D} \times \frac{\left(1-\phi_{\mathrm{c}, \mathrm{s}}\right)}{\left(1+\phi_{\mathrm{w}, \mathrm{s}}\right)} \times \frac{b-\Delta}{b-a+\left(b-a_{\mathrm{m}}\right) \times \frac{\left(C_{\mathrm{s}}-\Gamma\right) g_{0, \mathrm{sw}}+g_{1} P_{\mathrm{n}, \mathrm{L}} f\left(\theta_{\mathrm{s}}\right) f(D)}{\left(C_{\mathrm{s}}-\Gamma\right) g_{0, \mathrm{~m}}+g_{2} P_{\mathrm{n}, \mathrm{L}} f\left(\theta_{\mathrm{m}}\right) f(D)}}
$$

$$
\mathrm{WUE}_{\mathrm{s}, \mathrm{P}}=\frac{C_{\mathrm{a}}}{1.6 D} \times \frac{\left(1-\phi_{c, s}\right)}{\left(1+\phi_{w, s}\right)} \times \frac{b-\Delta}{b-a+\left(b-a_{\mathrm{m}}\right) \times \frac{\left(C_{\mathrm{s}}-\Gamma\right) g_{0, \mathrm{sw}}+g_{1} P_{\mathrm{n}, \mathrm{L}} f\left(\theta_{\mathrm{s}}\right) f(D)}{\left(C_{\mathrm{s}}-\Gamma\right) f\left(\theta_{\mathrm{m}}\right) g_{\mathrm{m}, \mathrm{p}}}}
$$

Obviously, in model configuration 1 (Eq. (16)), $g_{\mathrm{m}}$ was calculated by Eq. (4) with well parameterized $q_{\mathrm{m}}$ $\left(q_{\mathrm{m}}=0.25\right.$, see Results 3.2$)$, and $g_{\mathrm{sw}}$ was calculated by Eq. (2) with well parameterized $q_{\mathrm{s}}\left(q_{\mathrm{s}}=0.25\right.$, see Results 3.1). In model configuration 2 (Eq. (17)), $g_{\mathrm{m}}$ was calculated by Eq. (3) with well parameterized $q_{\mathrm{m}}\left(q_{\mathrm{m}}=0.50\right.$, see Results 3.2), and $g_{\mathrm{sw}}$ was calculated by Eq. (1).

\section{Material and Methods}

\subsection{Experimental design and management}

The experiment was carried out in April 2018 at the Chinese Forest Ecosystems Research Network $\left(116^{\circ} 05^{\prime} \mathrm{E}, 40^{\circ} 03^{\prime} \mathrm{N}\right)$, situated at Western Hill, Beijing, North China. In the experiment, 7-year-old Platycladus orientalis saplings with the same genotype of a temperate origin were transplanted into 15.51-L pots (one sampling per pot) containing soil collected from a local Platycladus orientalis stand. These samplings, with similar growth status and canopy structure (approximately $1.4 \mathrm{~m} \mathrm{high),} \mathrm{were}$ 
190

191

192

193

194

195

196

197

198

199

200

201

202

203

204

205

206

207

208

209

grown in a greenhouse. After acclimation in the greenhouse for 2 months, saplings were moved to growth chambers (FH-230, Taiwan Hipoint Corporation, Kaohsing City, Taiwan) and subjected to a nested design with three $C_{\mathrm{a}}$ levels and five SWC regimes.

The controlled environment (light, air temperature, and relative humidity) in the growth chambers was set to simulate natural growth conditions. From 07:00 to 19:00 (simulating daytime), all lights were turned on, with $60 \%$ relative humidity and $25^{\circ} \mathrm{C}$. From 19:00 to 07:00 (simulating nighttime), all lights were turned off, with $80 \%$ relative humidity and $18^{\circ} \mathrm{C}$. To realize orthogonal treatments, two growth chambers were used: one with ambient $C_{\mathrm{a}}\left(400 \mu \mathrm{mol} \cdot \mathrm{mol}^{-1}\right)$ and another one with elevated $C_{\mathrm{a}}(600$ and $800 \mu \mathrm{mol} \cdot \mathrm{mol}^{-1}$ ) levels. Each $C_{\mathrm{a}}$ treatment was subjected to five SWC regimes: 1) $35 \%-45 \%$ of field capacity, FC, (simulating severe drought), 2) $50 \%-60 \%$ of FC (moderate drought), 3) $60 \%-70 \%$ of FC (mild drought), 4) $70 \%-80 \%$ of FC (well-watered), and 5) 95\%-100\% of FC (excessively watered). The FC of the potting soil was $26.20 \%$. For the sake of calculative simplicity, we assumed that the SWC gradient was: 1) $10.48 \%$, 2) $14.41 \%$, 3) $17.03 \%$, 4) $19.65 \%$, and 5) $26.20 \%$, respectively. To reduce soil evaporation, the surface of the potting soil was covered with an approximately 2 -cm layer of perlite. The desired SWC regimes were achieved following the method from Zhang et al. (2019). Each treatment $\left(C_{a}\right.$ $\times$ SWC) lasted for 30 days and had three pot-grown saplings as replicates. One growth chamber was able to hold five pots, and the experiment was performed progressively from June to November 2018. The pots were rearranged frequently to exclude position effects.

\subsection{Measurements}

3.2.1 Whole-plant carbon balance and measurement

After the saplings had been subjected to the 30-day $C_{\mathrm{a}} \times \mathrm{SWC}$ treatment, whole-plant carbon balance was measured inside the growth chambers using the static chamber as designed by Jasoni et al. 
(2005). The static chamber measured $50 \times 50 \times 150 \mathrm{~cm}$, and in its interior, a pocket weather meter was incorporated (Kestrel 5500, Nielsen-Kellerman, Boothwyn, PA, USA) to monitor air temperature and pressure. To avoid soil respiration, the substrate surface was tightly sealed with airtight plastic film as described by Escalona et al. (2013). Prior to each measurement, the sapling was enclosed in the static chamber, and the fan on the top of the static chamber was turned on for 30 seconds to ensure that the flux was mixed well. The $C_{\mathrm{a}}$ in the static chamber was measured by an infrared gas analyzer (Li-8100, LiCor, Lincoln, NE, USA), starting after the flux was well mixed (initial $C_{\mathrm{a}}$, i.e., $C_{0}$ ) and finishing after the measurement had lasted for 3 minutes (final $C_{\mathrm{a}}$, i.e., $C_{\mathrm{l}}$ ). Measurements for each sapling were repeated three times and conducted at 9:00, 13:00, and 17:00 during daytime and at 22:00, 2:00, and 6:00 during nighttime. The whole-plant daytime net photosynthetic rate $\left(P_{\mathrm{n}, \mathrm{p}}\right)$ and the nighttime respiratory rate $\left(R_{\mathrm{p}}\right)$ were calculated as follows:

$$
\begin{aligned}
& P_{\mathrm{n}, \mathrm{P}}=\frac{V}{\Delta_{\mathrm{t}}} \times \frac{273.15}{\mathrm{~T}_{\mathrm{a}}} \times \frac{P}{101325} \times \frac{1}{22.41} \times\left(C_{0}-C_{\mathrm{l}}\right) \times \frac{60}{1000} \\
& R_{\mathrm{n}, \mathrm{P}}=\frac{\mathrm{V}}{\Delta_{\mathrm{t}}} \times \frac{273.15}{\mathrm{~T}_{\mathrm{a}}} \times \frac{\mathrm{P}}{101325} \times \frac{1}{22.41} \times\left(C_{1}-C_{0}\right) \times \frac{60}{1000}
\end{aligned}
$$

where $V$ is the chamber volume $(\mathrm{L})$ and $\Delta \mathrm{t}=3 \mathrm{~min}$ is the time duration. The $P_{\mathrm{n}, \mathrm{p}}$ and $\mathrm{R}_{\mathrm{p}}$ were calculated from values measured during daytime and nighttime, respectively.

\subsubsection{Whole-plant transpiration measurements}

The whole-plant daytime transpiration rate $\left(E_{\mathrm{p}}\right)$ was measured from the beginning until the end of the experiment by a Flow 32-1K system (Dynamax, Houston, TX, USA). The Flow 32-1K system includes gauges installed at approximately $25 \mathrm{~cm}$ above the stem base and a CR1000 logger (Campbell Scientific, Logan, UT, USA), which continuously collected $E_{\mathrm{p}}$ data every $15 \mathrm{~min}$.

The whole-plant nighttime transpiration rate $\left(E_{\mathrm{d}}\right)$ was measured by mass loss during the night. Total plant nighttime transpiration was obtained from the difference in pots weight at the onset (19:00) and 
end of night (7:00). During plant nighttime transpiration measurements, the substrate surface was tightly sealed with airtight plastic film as described by Escalona et al. (2013) to avoid soil evaporation. Measurements were made every 3 days.

The measured WUE $\mathrm{W}_{\mathrm{i}, \mathrm{P}}$ was the ratio between $P_{\mathrm{n}, \mathrm{p}}$ to $E_{\mathrm{p}}\left(P_{\mathrm{n}, \mathrm{p}} / E_{\mathrm{p}}\right)$, and the measured $\mathrm{WUE}_{\mathrm{s}, \mathrm{P}}$ was the ratio between accumulative carbon gain and cumulative water loss, that is, $\mathrm{WUE}_{\mathrm{s}, \mathrm{P}}=\left(P_{\mathrm{n}, \mathrm{P}}-R_{\mathrm{P}}\right) /\left(E_{\mathrm{P}}+\right.$ $E_{\mathrm{d})}$

\subsubsection{Leaf gas exchange and stable isotope analysis}

On the day of whole-plant carbon balance measurements, leaf gas change properties $\left(P_{\mathrm{n}, \mathrm{L}}, E_{\mathrm{L}}, g_{\mathrm{s}}\right.$, and $C_{\mathrm{i}}$ ), leaf temperature $\left(T_{\mathrm{L}}\right)$, and leaf surface relative humidity $(R H)$ were measured inside the growth chambers on fully expanded leaves, using an open gas exchange system (Li-6400, Li-Cor, Lincoln, NE, USA). The measurements were conducted at different positions (upper, middle, and lower crown) and made on at least three different leaves in each canopy layer at 9:00, 13:00, and 17:00. No significant differences $(p>0.05)$ in these measurements among different canopy layers were observed. Almost all leaves were exposed to similar light intensities, and thus, the effect of internal leaves was not considered. In this study, we assumed that a period of 30 days was long enough for saplings to be subjected to the treatments, according to our pilot experiment as described by Zhang et al. (2019). Measured leaf instantaneous water use efficiency $\left(\mathrm{WUE}_{\mathrm{i}, \mathrm{L}}\right)$ was calculated as the ratio between $P_{\mathrm{n}, \mathrm{L}}$ and $E_{\mathrm{L}}\left(P_{\mathrm{n}, \mathrm{L}} / E_{\mathrm{L}}\right)$.

The leaves used for gas exchange measurements were detached, immediately wrapped in tinfoil, and preserved in liquid nitrogen. Leaf water-soluble organic matter (WSOM) was extracted using the same method as described by Zhang et al. (2019). The obtained WSOM was dried and then combusted in an elemental analyzer (Flash EA 1112, Thermo Finnigan, Germany) coupled to a continuous-flow stable isotope ratio mass spectrometer (DELTAplusXP, Thermo Finnigan, Germany). The $\delta^{13} \mathrm{C}$ of leaf 


\subsubsection{Whole-plant total leaf area measurement} was calculated as follows:

$$
L A=R_{\mathrm{D}} \times D W=\left(L A_{\text {sub }} / D W_{\text {sub }}\right) \times\left(D W_{\text {sub }}+D W_{\text {rest }}+D W_{\text {iso }}\right) .
$$

In this equation, $R_{\mathrm{D}}$ is leaf area per dry weight $\left(\mathrm{m}^{2} \cdot \mathrm{g}^{-1}\right), D W$ is whole-plant total dry weight $(\mathrm{g})$, and $D W_{\text {iso }}$ (=FW $W_{\text {iso }} \times D W_{\text {sub }} / F W_{\text {sub }}$, with $F W_{\text {iso }}$ referring to fresh weight of leaves used for isotope analysis in $\mathrm{g}$ ) is dry weight of leaves used for isotope analysis $(\mathrm{g})$.

All statistical analyses were conducted using SPSS 19.0. The influences of $C_{\mathrm{a}}$ and SWC on mean variables of $g_{\mathrm{sw}}, g_{\mathrm{m}}$, and WUE (including $\mathrm{WUE}_{\mathrm{i}, \mathrm{L}}, \mathrm{WUE}_{\mathrm{i}, \mathrm{P}}$, and $\mathrm{WUE}_{\mathrm{s}, \mathrm{P}}$ ) were determined by two-way analysis of variance (ANOVA). Results were considered statistically significant at $p<0.05$. Deviations of the modeled $g_{\mathrm{sw}}, g_{\mathrm{m}}$, and WUE from their measurements were absolute differences between the modeled and measured values. Relationships between the measured and modeled values in $g_{\mathrm{sw}}, g_{\mathrm{m}}$, and 


\section{Results}

4.1 Measured and modeled responses of $g_{\mathrm{sw}}$ to SWC and $C_{\mathrm{a}}$

Changes in SWC and $C_{\mathrm{a}}$ led to significant effects on $g_{\mathrm{sw}}(p<0.05)$, with a maximum of 0.0963 mmol $\mathrm{H}_{2} \mathrm{O} \cdot \mathrm{m}^{-2} \cdot \mathrm{s}^{-1}$ at $\mathrm{C}_{400} \times 19.65 \%$ of $\mathrm{SWC}$ and a minimum of $0.0155 \mathrm{~mol} \mathrm{H} \mathrm{H}_{2} \mathrm{O} \cdot \mathrm{m}^{-2} \cdot \mathrm{s}^{-1}$ (Fig. 1). Irrespective of $C_{\mathrm{a}}, g_{\mathrm{sw}}$ increased sharply as water stress was alleviated, and this effect was less evident when SWC exceeded $17.03 \%$ and even decreased when $g_{\text {sw }}$ peaked at $19.65 \%$ of SWC. In all cases, $g_{\text {sw }}$ increased with elevated $C_{\mathrm{a}}$ (Fig. 1).

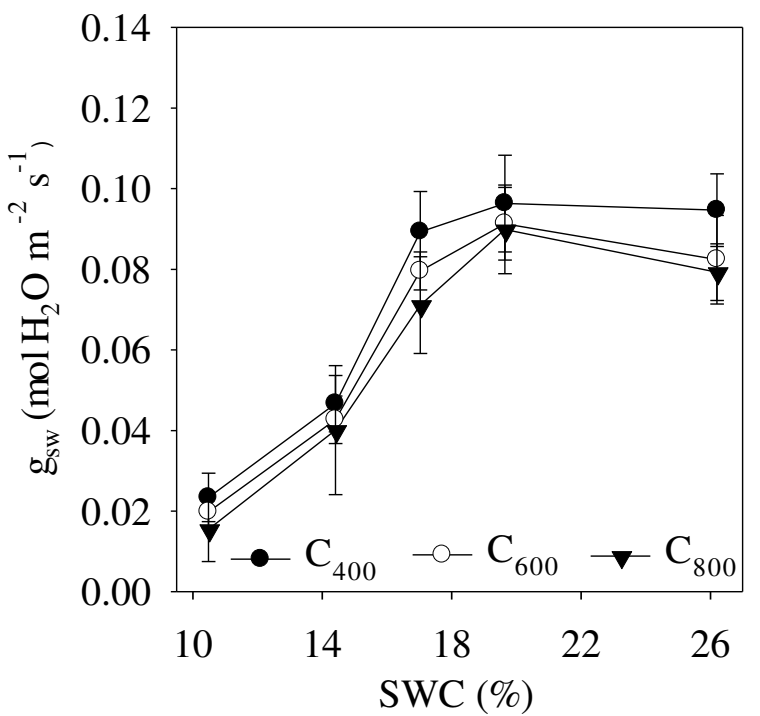

Fig. 1 Response of measured leaf stomatal conductance $\left(\mathrm{g}_{\mathrm{sw}}\right)$ to three $\mathrm{CO}_{2}$ concentrations $\left(C_{\mathrm{a}}\right) \times$ five soil water contents (SWC) for Platycladus orientalis saplings. Data represent mean values \pm SD.

In the absence of additional parameterization associated with soil water stress, the $g_{\mathrm{sw}}$ simulated by the coupled $P_{\mathrm{n}, \mathrm{L}}-g_{\mathrm{sw}}$ model (Eq. 1) decreased in response to elevated $C_{\mathrm{a}}$, but increased as the soil water status improved and reached maximum values at $19.65 \%$ of SWC, with a slight decrease thereafter (Fig. 2). In contrast, when the effect of soil water stress was incorporated in the coupled $P_{\mathrm{n}, \mathrm{L}}-g_{\mathrm{sw}}$ model (Eq. 2), the simulated $g_{\mathrm{sw}}$ generally increased as SWC increased, regardless of the value imposed by $q_{\mathrm{s}}$. More specifically, at any given $C_{\mathrm{a}}$, the amplification in simulated $g_{\mathrm{s}}$ by SWC was much greater as the $q_{\mathrm{s}}$ 
decreased with SWC below $17.03 \%$, while the opposite trend was observed when SWC exceeded 19.65\%.

When the SWC improved from 17.03 to $19.65 \%$, the reduction of $q_{\mathrm{s}}$ led to a higher amplification in simulated $g_{\mathrm{sw}}$ at ambient $C_{\mathrm{a}}\left(\mathrm{C}_{400}\right)$ (Fig. 2a), while the amplitude was similar by imposing different $q_{\mathrm{s}}$ levels at elevated $C_{\mathrm{a}}\left(\mathrm{C}_{600}\right.$ and $\left.\mathrm{C}_{800}\right)$ (Figs. $2 \mathrm{~b}$ and $\left.2 \mathrm{c}\right)$.

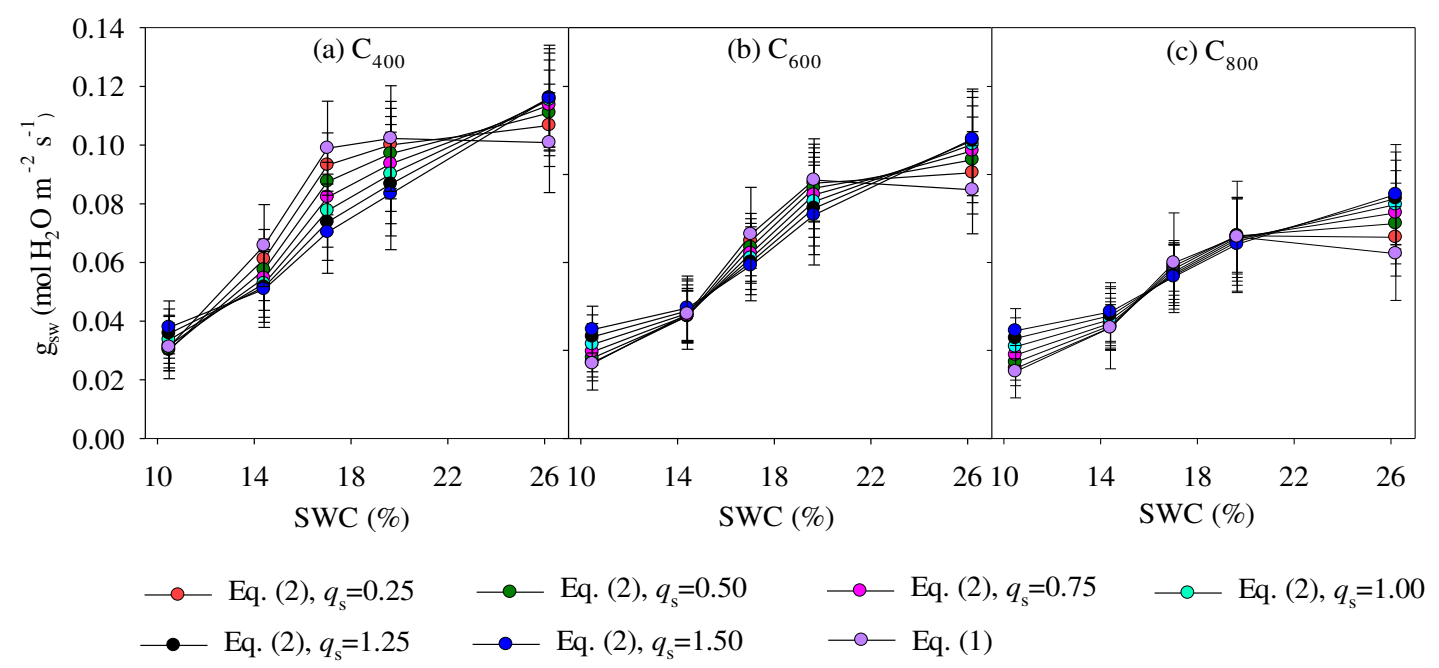

Fig. 2 Leaf stomatal conductance ( $\left.g_{\text {sw }}\right)$ estimated by different models (Eqs. (1) and (2)) of Platycladus orientalis saplings under five soil water contents $(\mathrm{SWC}) \times$ three $\mathrm{CO}_{2}$ concentrations $\left(C_{\mathrm{a}}\right)$ conditions.

Data represent mean values $\pm \mathrm{SD}$.

The regression analysis between measured and modeled $g_{\mathrm{sw}}$ is presented in Figure 3 . When $g_{\mathrm{sw}}$ was calculated from Eq. (2), the modeled values were significantly related with measurements $(p<0.01)$, and the correlation coefficient $R^{2}$ decreased from 0.88 to 0.68 as $q_{\mathrm{s}}$ increased from 0.25 to 1.50 (Fig. 3). The $g_{\text {sw }}$ calculated from Eq. (1) was also significantly correlated with measurements $(p<0.01)$, with $R^{2}$ being equal to 0.87 . However, estimates of $g_{\mathrm{sw}}$ from Eq. (2), using $q_{\mathrm{s}}=0.25$, showed slightly better agreements (higher $R^{2}$ and slope closer to 1) with measurements than estimates from Eq. (1), and the former caused less deviation $\left(0.0084 \pm 0.0053 \mathrm{~mol} \mathrm{H}{ }_{2} \mathrm{O} \cdot \mathrm{m}^{-2} \cdot \mathrm{s}^{-1}\right)$ from the measured results than the latter $(0.0086 \pm$ $0.0062 \mathrm{~mol} \mathrm{H} \mathrm{H}_{2} \mathrm{O} \cdot \mathrm{m}^{-2} \cdot \mathrm{s}^{-1}$ ) (Fig. 3), indicating that Eq. (2) using $q_{\mathrm{s}}=0.25$ for $g_{\mathrm{sw}}$ outperformed Eq. (1). 


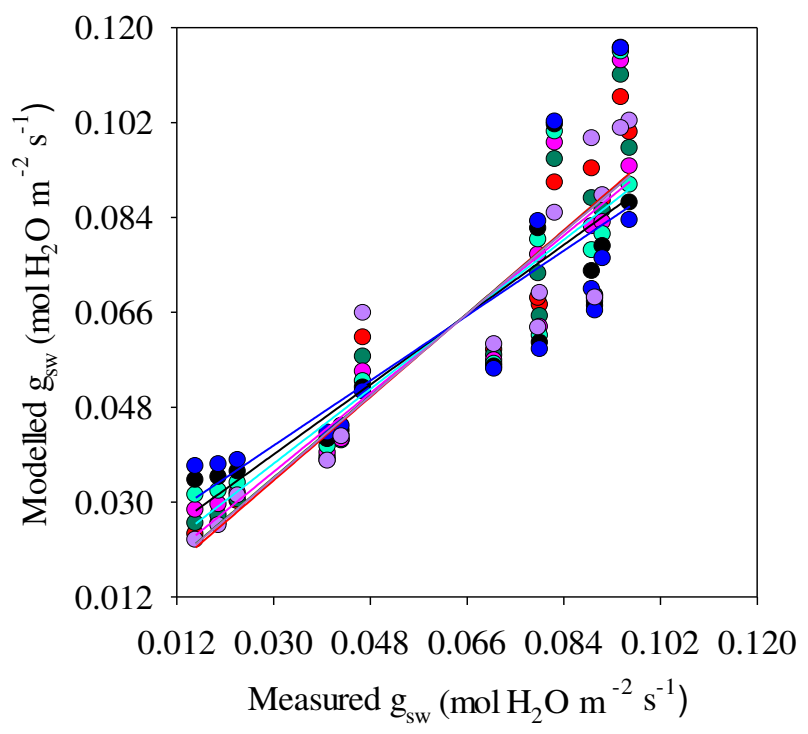

- Eq. (2), $q_{\mathrm{s}}=0.25-y=0.88 x+0.01, \mathrm{R}^{2}=0.88, P<0.01$

- Eq. (2), $q_{\mathrm{s}}=0.50-y=0.86 x+0.01, \mathrm{R}^{2}=0.86, P<0.01$

- Eq. (2), $q_{\mathrm{s}}=0.75-y=0.83 x+0.01, \mathrm{R}^{2}=0.83, P<0.01$

- Eq. (2), $q_{\mathrm{s}}=1.00-y=0.79 x+0.01, \mathrm{R}^{2}=0.79, P<0.01$

- Eq. (2), $q_{\mathrm{s}}=1.25-y=0.74 x+0.02, \mathrm{R}^{2}=0.74, P<0.01$

- Eq. (2), $q_{\mathrm{s}}=1.50-y=0.68 x+0.02, \mathrm{R}^{2}=0.68, P<0.01$

- Eq. (1)

$y=0.87 x+0.01, \mathrm{R}^{2}=0.87, P<0.01$

Fig. 3 Correlation analysis between measured and modeled leaf stomatal conductance $\left(g_{\mathrm{sw}}\right)$ values of

different models (Eqs. (1) and (2)).

4.2 Measured and modeled responses of $\mathrm{g}_{\mathrm{m}}$ to $\mathrm{SWC}$ and $C_{\mathrm{a}}$ 


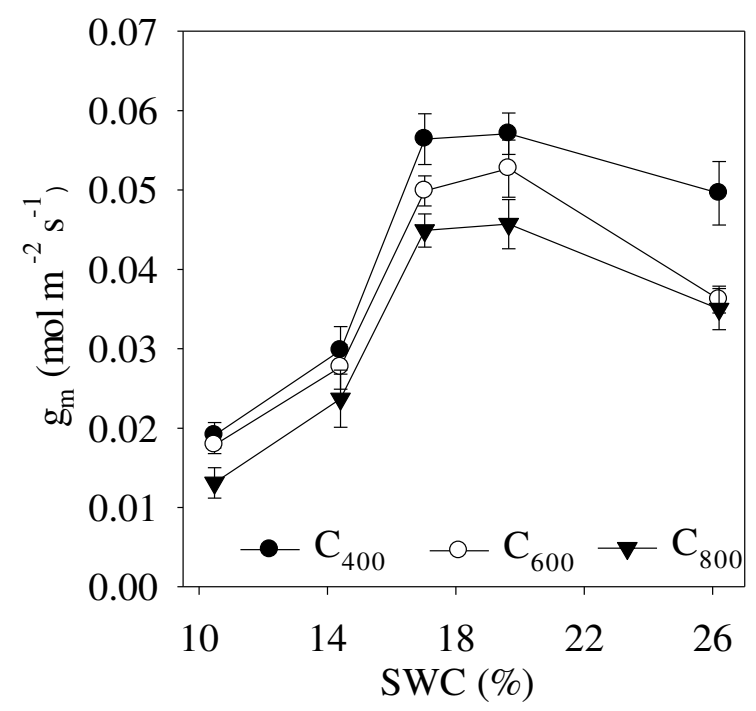

320 Fig. 4 Response of measured leaf mesophyll conductance $\left(g_{\mathrm{m}}\right)$ to three $\mathrm{CO}_{2}$ concentrations $\left(C_{\mathrm{a}}\right) \times$ five

321 soil water contents (SWC) for Platycladus orientalis saplings. Data represent mean values \pm SD.

The simulated $g_{\mathrm{m}}$, calculated by the SWC- and $g_{\mathrm{m}, 0}$-dependent function (Eq. (3)) and the coupled $P_{\mathrm{n}, \mathrm{L}}-g_{\mathrm{m}}$ model (Eq. (4)), is presented in Fig. 5. Regardless of the model used, the simulated $g_{\mathrm{m}}$ decreased in response to an increased $C_{a}$ (Fig. 5). Applying Eq. (3), the simulated $g_{m}$ approximately increased linearly with increasing SWC levels and tended to be higher with decreasing levels of the imposed $q_{\mathrm{m}}$, except at excessive-watered conditions (25.55\% of SWC). In contrast, the simulated $g_{\mathrm{m}}$ calculated by Eq.

327 (4), using various $q_{\mathrm{m}}$ values, produced a more complicated tendency to SWC. At any given $C_{\mathrm{a}}$, the amplification was more obvious due to the rapid reduction in $q_{\mathrm{m}}$ at $\mathrm{SWC}$ levels below $17.03 \%$, while the opposite pattern was observed when SWC exceeded 19.65\%. When the SWC increased from 17.03 to $19.65 \%$, the reduction in $q_{\mathrm{m}}$ induced a decrease in the amplification of the simulated $g_{\mathrm{m}}$ at ambient $C_{\mathrm{a}}$

331 (Fig. 5b), while the amplification was similar for different $q_{\mathrm{s}}$ levels at elevated $C_{\mathrm{a}}\left(\mathrm{C}_{600}\right.$ and $\left.\mathrm{C}_{800}\right)($ Figs. 

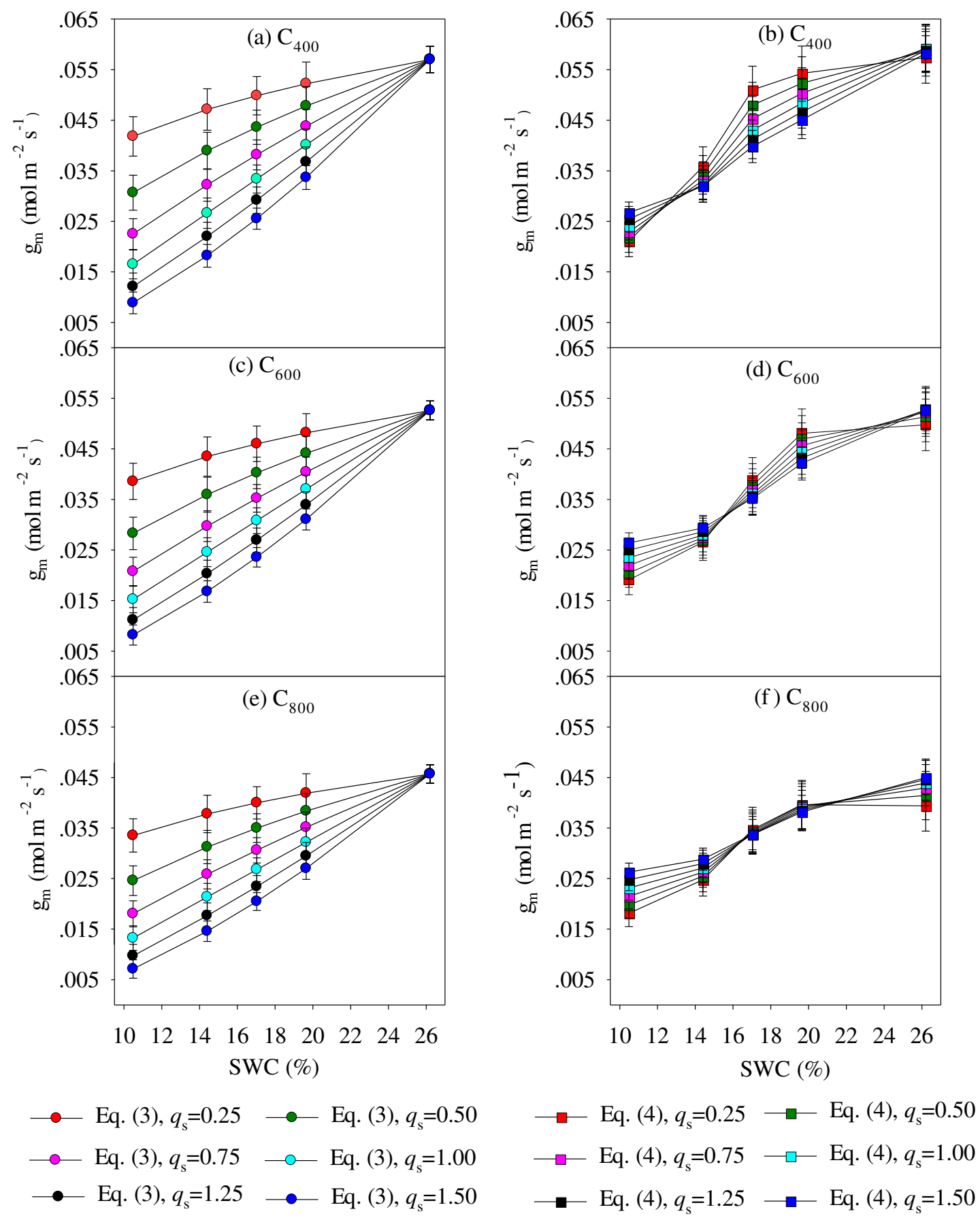

Fig. 5 Leaf mesophyll conductance $\left(g_{\mathrm{m}}\right)$ estimated by different models (Eqs. (3) and (4)) under five soil water contents $(\mathrm{SWC}) \times$ three $\mathrm{CO}_{2}$ concentrations $\left(C_{\mathrm{a}}\right)$. Data represent mean values $\pm \mathrm{SD}$. between simulated and measured results ( $p<0.05)$. Using Eq. (3), the highest $R^{2}$ between measured and 


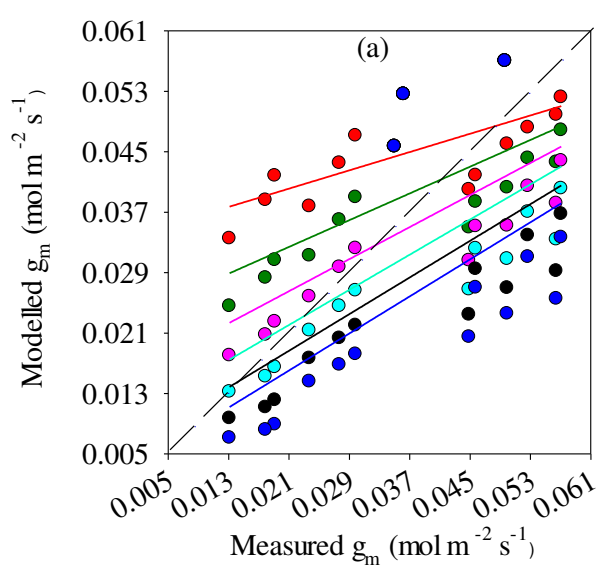

- Eq. (3), $q_{\mathrm{m}}=0.25-y=0.30 x+0.03, R^{2}=0.50, P<0.01$

- Eq. (3), $q_{\mathrm{m}}=0.50-y=0.44 x+0.02, R^{2}=0.52, P<0.01$

- Eq. (3), $q_{\mathrm{m}}=0.75-y=0.53 x+0.02, R^{2}=0.48, P<0.05$

- Eq. (3), $q_{\mathrm{m}}=1.00-y=0.58 x+0.01, R^{2}=0.43, P<0.05$

- Eq. (3), $q_{\mathrm{m}}=1.25-y=0.61 x+0.01, R^{2}=0.38, P<0.05$

- Eq. (3), $q_{\mathrm{m}}=1.50-y=0.61 x+0.003, R^{2}=0.34, P<0.05$

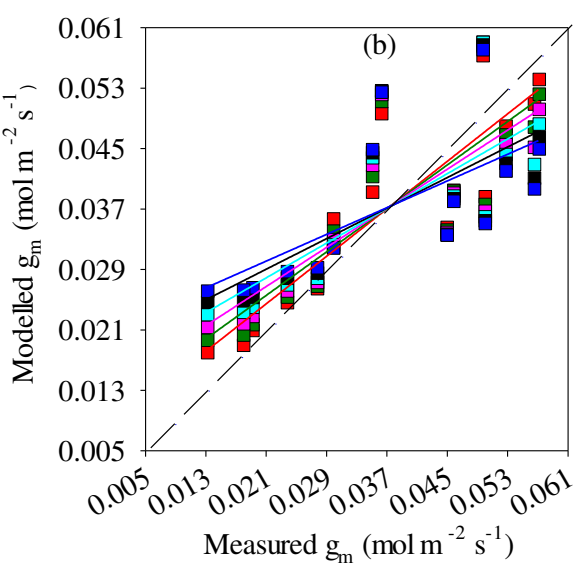

- Eq. (4), $q_{\mathrm{m}}=0.25-y=0.79 x+0.01, R^{2}=0.79, P<0.01$

- Eq. (4), $q_{\mathrm{m}}=0.50-y=0.72 x+0.01, R^{2}=0.72, P<0.01$

- Eq. (4), $q_{\mathrm{m}}=0.75-y=0.65 x+0.01, R^{2}=0.65, P<0.01$

Eq. (4), $q_{\mathrm{m}}=1.00-y=0.57 x+0.02, R^{2}=0.57, P<0.01$

- Eq. (4), $q_{\mathrm{m}}=1.25-y=0.51 x+0.02, R^{2}=0.51, P<0.01$

- Eq. (4), $q_{\mathrm{m}}=1.50-y=0.44 x+0.02, R^{2}=0.44, P<0.01$

Fig. 6 Correlation analysis between measured and modeled leaf mesophyll conductance $\left(g_{\mathrm{m}}\right)$ using 
that the simulated $\mathrm{WUE}_{\mathrm{i}, \mathrm{L}}$ increased as the $\mathrm{SWC}$ improved from 14.41 to $17.03 \%$ at $\mathrm{C}_{400}$ and $\mathrm{C}_{600}$, departing from the observed decreasing trend (Fig. 7a).

At the whole-plant level, a significant effect of $C_{\mathrm{a}}$ and SWC on the measured instantaneous WUE $\left(\mathrm{WUE}_{\mathrm{i}, \mathrm{P}}\right)$ was observed $(p<0.05)$. In general, the $\mathrm{WUE}_{\mathrm{i}, \mathrm{P}}$ was higher at elevated $C_{\mathrm{a}}$ levels (Fig. $\left.7 \mathrm{~b}\right)$. When the SWC increased from $10.48 \%$ to $14.41 \%$, the percentage increase in the measured WUE $\mathrm{E}_{\mathrm{i}, \mathrm{P}}$ was more pronounced at $\mathrm{C}_{800}$ than at $\mathrm{C}_{400}$ and $\mathrm{C}_{600}$. In response to further increases in $\mathrm{SWC}$, the measured $\mathrm{WUE}_{\mathrm{i}, \mathrm{P}}$ generally decreased sharply, but this impact was less evident when the soil water status was more than $19.65 \%$ of SWC. In both model configurations, the measured and simulated $\mathrm{WUE}_{\mathrm{i}, \mathrm{P}}$ values were similar in their response patterns to SWC $\times C_{\mathrm{a}}$, except when the SWC increased from $14.41 \%$ to $17.03 \%$ at $\mathrm{C}_{400}$ and $\mathrm{C}_{600}$ (Fig. 7b).
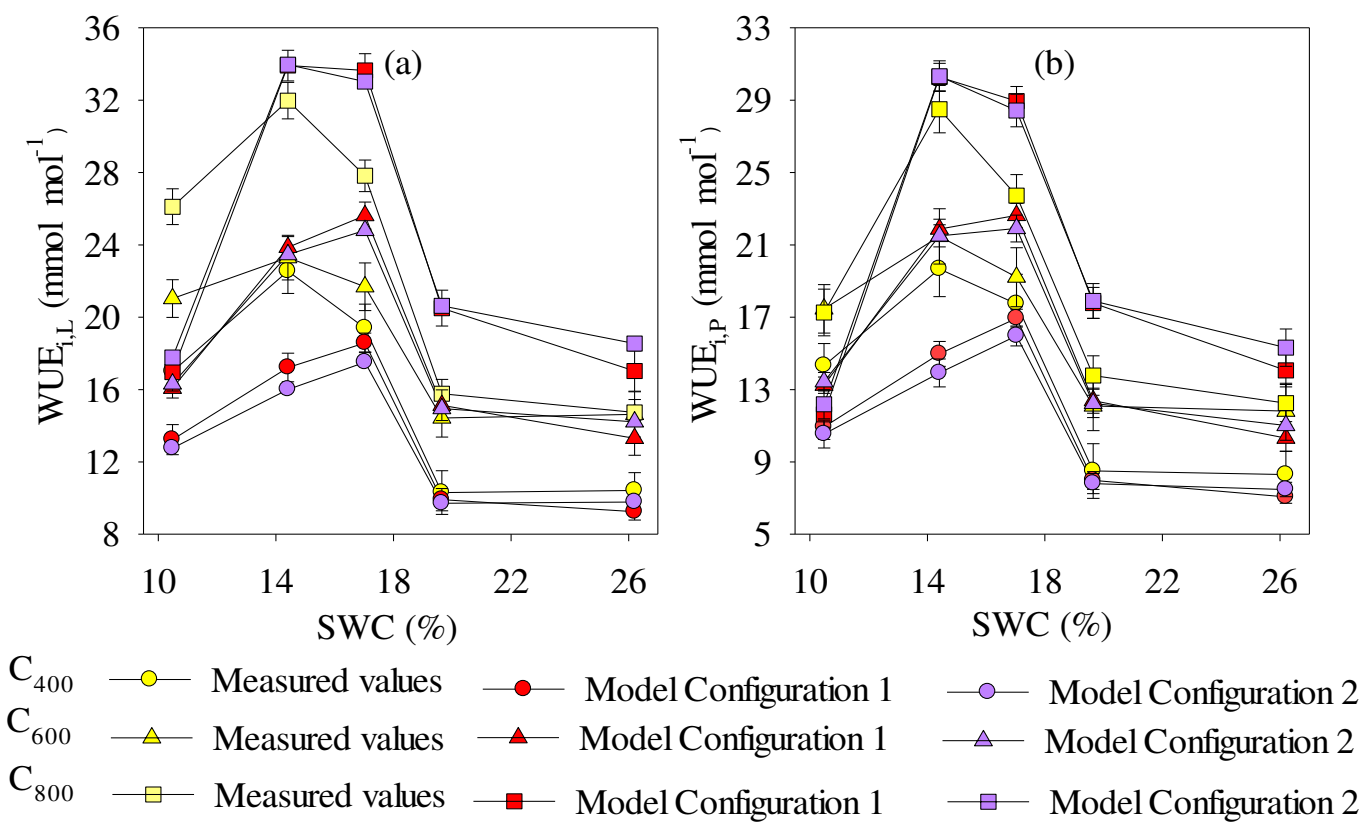

Fig. 7 Measured and simulated leaf (WUE $\mathrm{W}_{\mathrm{i}-\mathrm{L}}$; a) and whole-plant level instantaneous water use efficiency (WUE $\left.\mathrm{i}_{\mathrm{i}} ; \mathrm{b}\right)$ in different model configurations of Platycladus orientalis saplings under five soil water contents $(\mathrm{SWC}) \times$ three $\mathrm{CO}_{2}$ concentrations $\left(C_{\mathrm{a}}\right)$ conditions. Data represent mean values $\pm \mathrm{SD}$.

At the leaf and the whole-plant level, the measured and modeled instantaneous WUE values were 
significantly correlated in both model configurations $(p<0.01)$; however, the $R^{2}$ values in model configuration $1(\mathrm{C} 1)$ were slightly higher than those in model configuration $2(\mathrm{C} 2)$ (Fig. 8). Estimates of $\mathrm{WUE}_{\mathrm{i}, \mathrm{L}}\left(\mathrm{WUE}_{\mathrm{i}, \mathrm{P}}\right)$ in $\mathrm{C} 1$ caused a deviation of $3.12 \pm 2.44(2.59 \pm 1.86) \mathrm{mmol} \cdot \mathrm{mol}^{-1}$ from the measured results, which was slightly less than that caused in C2 with a deviation of $3.14 \pm 2.52(2.62 \pm 1.90)$ $\mathrm{mmol} \cdot \mathrm{mol}^{-1}$ (Fig. 8). This indicates that the $\mathrm{C} 1$ for $\mathrm{WUE}_{\mathrm{i}, \mathrm{L}}$ and $\mathrm{WUE}_{\mathrm{i}, \mathrm{P}}$ behaved slightly better than the $\mathrm{C} 2$.

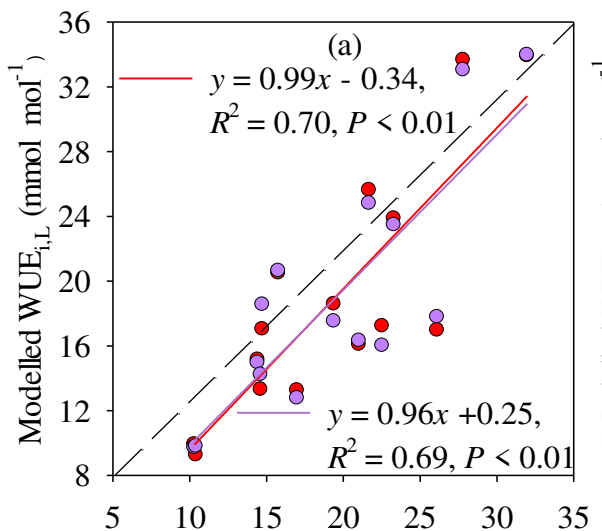

Measured $\mathrm{WUE}_{\mathrm{i}, \mathrm{L}}\left(\mathrm{mmol} \mathrm{m} \mathrm{m}^{-2} \mathrm{~s}^{-1}\right)$

- Model Configuration 1

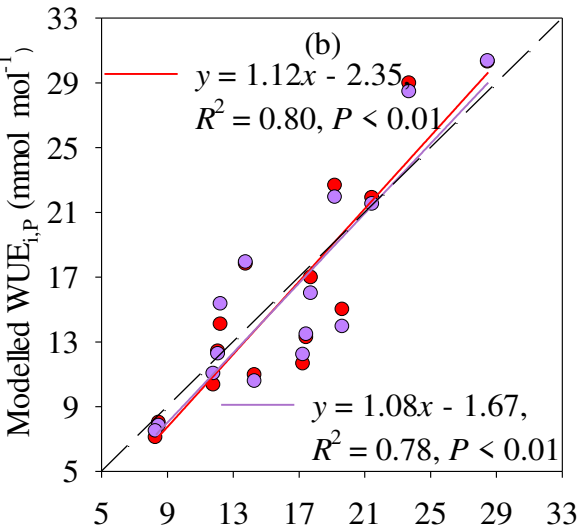

Measured $\mathrm{WUE}_{\mathrm{i}, \mathrm{P}}\left(\mathrm{mmol} \mathrm{m} \mathrm{m}^{-2} \mathrm{~s}^{-1}\right)$

- Model Configuration 2

Fig. 8 Correlation analysis between measured and modeled results of leaf instantaneous water use

efficiency (WUE $\mathrm{i}_{\mathrm{i}-\mathrm{L}}$ ) estimated by different model configurations (a), as well as between measured and modeled results of whole-plant instantaneous water use efficiency (WUE-P) estimated by different model configurations (b).

\subsection{Comparison of measured and modeled $\mathrm{WUE}_{\mathrm{s}, \mathrm{P}}$ values}

The measured and simulated $\mathrm{WUE}_{\mathrm{s}, \mathrm{P}}$ values are shown in Figure 9. At severe drought $(10.48 \%$ of SWC), the measured $\mathrm{WUE}_{\mathrm{s}, \mathrm{P}}$ peaked at $\mathrm{C}_{600}$ and was lowest at $\mathrm{C}_{800}$, while the simulated $\mathrm{WUE}_{\mathrm{s}, \mathrm{P}}$, in both model configurations, reached its maximum at $\mathrm{C}_{600}$ and its minimum at $\mathrm{C}_{400}$ (Fig. 9). At an improved soil water status ( $\mathrm{SWC}$ at $14.41 \% \sim 25.55 \%$ ), the measured and simulated $\mathrm{WUE}_{\mathrm{s}, \mathrm{P}}$ values significantly increased due to elevated $C_{\mathrm{a}}$ levels $(p<0.01)$. The measured $\mathrm{WUE}_{\mathrm{s}, \mathrm{P}}$ was also significantly influenced 


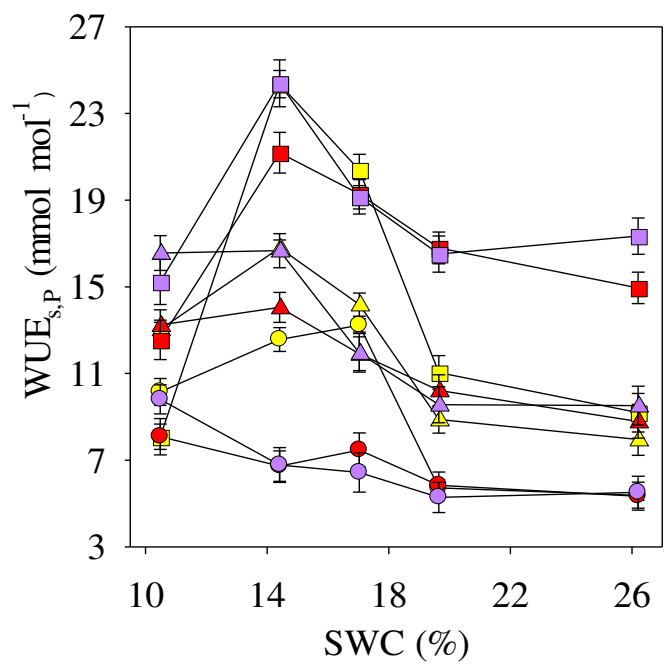

$\mathrm{C}_{400} \longrightarrow$ Measured values $\longrightarrow$ Model Configuration $1 \multimap$ Model Configuration 2 $\mathrm{C}_{600} \longrightarrow$ Measured values $\longrightarrow$ Model Configuration $1 \multimap$ Model Configuration 2 $\mathrm{C}_{800}-$ Measured values $\longrightarrow$ Model Configuration $1 \longrightarrow$ Model Configuration 2

Fig. 9 Measured and modeled whole-plant short-term water use efficiency (WUE $\left.E_{s, P}\right)$ values of Platycladus orientalis saplings under five soil water contents $(\mathrm{SWC}) \times$ three $\mathrm{CO}_{2}$ concentrations $\left(C_{\mathrm{a}}\right)$ conditions. Data represent mean values \pm SD. 


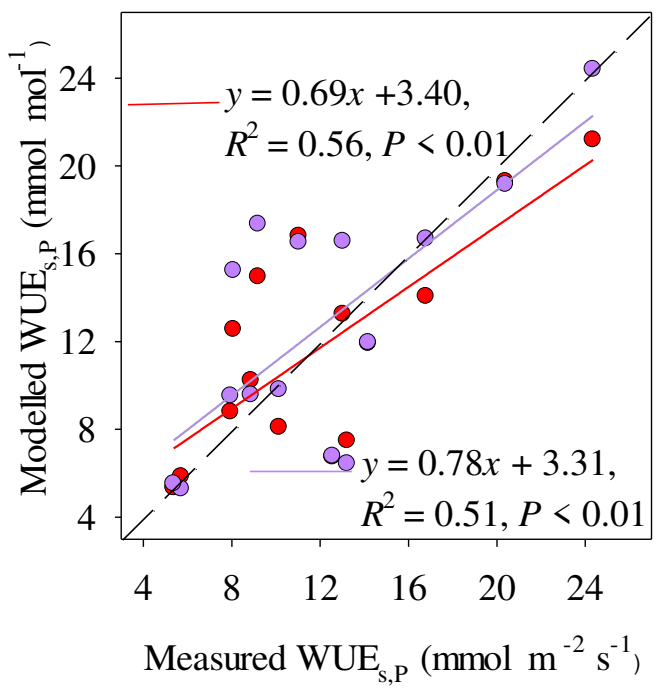

\section{- Model Configuration $1 \bigcirc$ Model Configuration 2}

401 Fig. 10 Correlation analysis between measured and modeled whole-plant short-term water use efficiency

$402\left(\mathrm{WUE}_{\mathrm{s}, \mathrm{P}}\right)$ values.

\section{Discussion}

\section{Model performance for estimating $g_{\mathrm{sw}}$ and $g_{\mathrm{m}}$}

Soil water stress exclusion in the coupled $P_{\mathrm{n}, \mathrm{L}}-g_{\mathrm{sw}}$ model (Eq. (1)) for response patterns of $g_{\mathrm{sw}}$

performed reasonably well under non-limiting soil water conditions (Fig. 3), which is in agreement with 
soil water status, resulting in the estimation of $g_{\mathrm{sw}}$ from the coupled $A_{\mathrm{n}}-g_{\mathrm{sw}}$ model account for the effect of soil water.

The Keenan et al. (2010) model (Eq. (3)) for $g_{\mathrm{m}}$ was insufficient to take into account the impact of $C_{\mathrm{a}}$ and was therefore less suitable to simulate $g_{\mathrm{m}}$ (Fig. 6). In contrast, the predictive accuracy improved considerably when estimating $g_{\mathrm{m}}$ using the coupled $P_{\mathrm{n}, \mathrm{L}}-\mathrm{g}_{\mathrm{m}}$ model (Eq. (4)) (Fig. 6). Therefore, the proposed coupled $P_{\mathrm{n}, \mathrm{L}}-\mathrm{g}_{\mathrm{m}}$ model is valid and promising for simulating $g_{\mathrm{m}}$, despite its phenomenological nature and its dependence upon physiological hypotheses. Furthermore, imposing $q_{\mathrm{m}}=0.25$ in Eq. (4) provided the best fit with the measured values (Fig. 6), indicating that the limitation strength of $g_{\mathrm{m}}$ was similar to that of $g_{\mathrm{sw}}$. This result conflicts with the general findings that stomatal behavior imposed a higher limitation to photosynthesis than mesophyll behavior (Egea et al., 2011a; Galmes et al., 2007; Grassi and Magnani, 2005); however, this phenomenon may not always occur. Pérez-Martín et al. (2009) observed minor difference between stomatal and mesophyll limitations and reported that stiffer and more sclerophyllous leaves would provide greater mesophyll resistance during $\mathrm{CO}_{2}$ diffusion. The response pattern of $g_{\mathrm{m}}$ to $C_{\mathrm{a}}$ and SWC resembled that for $g_{\mathrm{sw}}$ (Figs. 1 and 4), leading to a tight correlation of $g_{\mathrm{m}}$ with $g_{\text {sw }}\left(P<0.01, R^{2}=0.83\right)$; this has also been observed for Douglas fir (Bögelein et al., 2012; Ethier et al., 2006). The ratio $g_{\mathrm{m}} / g_{\mathrm{sw}}$ tends to be higher in drought than in irrigated conditions (Pérez-Martín et al., 2009), which was also the case in this study. This demonstrates that the previously proposed hypothesis that $g_{\mathrm{sw}}$ is proportional to $g_{\mathrm{m}}$ with almost a constant ratio (Lauteri et al., 1997; Ohsumi et al., 2007) is not always valid.

\section{Different model configurations for estimating $\mathrm{WUE}_{\mathrm{s}, \mathrm{P}}$}

In the proposed short-term WUE model (Eq. (15)), scaling up from leaf to whole-plant level, there are diffusive limitation parameters. The coupled $P_{\mathrm{n}, \mathrm{L}}-g_{\mathrm{sw}}$ model, incorporating the water stress-dependent 
function with well parameterized $q_{\mathrm{s}}$ (Eq. (2)), slightly more accurately captured the observed $g_{\mathrm{sw}}$ pattern than the model excluding the soil water stress effect (Eq. (1)) (Fig. 3), and the proposed coupled $P_{\mathrm{n}, \mathrm{L}}-g_{\mathrm{m}}$ model with well parameterized $q_{\mathrm{m}}$ (Eq. (4)) effectively improved the predictive accuracy of $g_{\mathrm{m}}$ compared to the previously introduced $g_{\mathrm{m}, \mathrm{p}^{-}}$and SWC-dependent model (Eq. (3)) (Fig. 6). Therefore, the $\mathrm{Cl}$ inferred from Eqs. (2) and (4) could more accurately represent the observed WUE $\mathrm{s}_{\mathrm{s}, \mathrm{P}}$ than the $\mathrm{C} 2$ inferred from Eqs. (1) and (3) (Fig. 10). This leads us to infer that the model scaling-up from leaf to whole-plant level, based on more accurate predictions of stomatal and mesophyll behavior, could be used to estimate $\mathrm{WUE}_{\mathrm{s}, \mathrm{P}}$ with a high level of precision.

The developed model for estimating $\mathrm{WUE}_{\mathrm{s}, \mathrm{P}}$ also contains photosynthetic parameters by introducing the coupled $P_{\mathrm{n}, \mathrm{L}}-g_{\mathrm{sw}}$ and $P_{\mathrm{n}, \mathrm{L}}-g_{\mathrm{m}}$ models. Rather than estimating $P_{\mathrm{n}, \mathrm{L}}$ via the photosynthesis model (Jones 1992; Yu et al., 2001), neither model configuration 1 nor model configuration 2 for $\mathrm{WUE}_{\mathrm{s}, \mathrm{P}}$ simulate $P_{\mathrm{n}, \mathrm{L}}$ from environmental and physiological factors. The estimates of $\mathrm{WUE}_{\mathrm{s}, \mathrm{P}}$ were calculated from measured $P_{\mathrm{n}, \mathrm{L}}$ values in order to exclude the situation that errors in the representation of $g_{\mathrm{sw}}$ and $g_{\mathrm{m}}$ might be compensated or overwhelmed by errors in simulated $P_{\mathrm{n}, \mathrm{L}}$. In such a situation, we can identify the influence of precision of stomatal and mesophyll modelling on the credibility and accuracy of the developed $\mathrm{WUE}_{\mathrm{s}, \mathrm{P}}$ model. For $\mathrm{WUE}_{\mathrm{i}, \mathrm{L}}$ and $\mathrm{WUE}_{\mathrm{i}, \mathrm{P}}$ modelling, the $\mathrm{C} 1$ inferred from the more accurate $g_{\text {sw }}$ model incorporating a soil water stress-dependent function (Eq. (2)) slightly outperformed the C2 (Figs. $8 \mathrm{a}$ and $8 \mathrm{~b}$ ). However, the $R^{2}$ between measured and modeled values of $\mathrm{WUE}_{\mathrm{s}, \mathrm{P}}$ were lower than those of $\mathrm{WUE}_{\mathrm{i}, \mathrm{L}}$ and $\mathrm{WUE}_{\mathrm{i}-\mathrm{P}}$ (Figs. 8 and 10), most likely because involvement of more parameters in the isotope-inferred $\mathrm{WUE}_{\mathrm{s}, \mathrm{P}}$ model could introduce more uncertainties and errors. For example, complications arising from post-photosynthetic carbon isotope fractionations are not considered, as the process is still difficult to assess and largely unknown (Tcherkez et al., 2005; Wingate et al., 2007). 
Furthermore, the effects of photorespiration and mitochondrial respiration on photosynthetic ${ }^{13} \mathrm{C}$ discrimination are still subject of debate (Douthe et al., 2012) and were thus ignored.

\section{Uncertainties of WUE, $\mathrm{P}$ introduced by $g_{\mathrm{sw}}$ and $g_{\mathrm{m}}$}

To further determine the uncertainties of $\mathrm{WUE}_{\mathrm{s}, \mathrm{P}}$ associated with simulations of stomatal and mesophyll behavior, uncertainty analysis was conducted. Using the most effective approach to reproduce $g_{\text {sw }}$ (Eq. (2), with tunable parameter $q_{\mathrm{s}}=0.25$ ) and $g_{\mathrm{m}}$ (Eq. (4), with tunable parameter $q_{\mathrm{m}}=0.25$ ), the average (s.d.) uncertainties in $g_{\mathrm{sw}}$ and $\mathrm{g}_{\mathrm{m}}$ were $17.10 \%$ (14.14\%) and $15.39 \%(10.98 \%)$, respectively. The WUE $_{\mathrm{s}, \mathrm{P}}$ estimated from $\mathrm{C} 1$ caused average uncertainties of $24.09 \%(21.61 \%)$. The relative small discrepancies between mean value and standard deviation in uncertainties of $g_{\mathrm{sw}}, g_{\mathrm{m}}$, and WUE $\mathrm{s}, \mathrm{P}$ indicate that these estimation methods were not stable, although model performance was improved. In addition, the $\mathrm{WUE}_{\mathrm{s}, \mathrm{P}}$ was more sensitive to $g_{\mathrm{sw}}$ than to $g_{\mathrm{m}}$. That is, $10 \%$ error in $g_{\mathrm{sw}}$ introduced $6.17 \%$ error in $\mathrm{WUE}_{\mathrm{s}, \mathrm{P}}$, while $10 \%$ error in $g_{\mathrm{m}}$ introduced less error of $4.48 \%$ in $\mathrm{WUE}_{\mathrm{s}, \mathrm{P}}$. Although the stomatal and mesophyll limitations were similar to those of the photosynthetic process in this study, the leaf transpiration is exclusively controlled by $g_{\mathrm{sw}}$ when the $v$ is almost constant (Seibt et al., 2008; Zhao et al., 2017; Zhang et al., 2019), which could result in the $g_{\mathrm{sw}}$ being more influential for $\mathrm{WUE}_{\mathrm{s}, \mathrm{P}}$ than for $g_{\mathrm{m}}$

Overall, the explored model for $\mathrm{WUE}_{\mathrm{s}, \mathrm{P}}$, scaling from leaf to whole-plant level, is based on wellcharacterized coupled $P_{\mathrm{n}, \mathrm{L}}-g_{\mathrm{sw}}$ (Eq. (2)) and $P_{\mathrm{n}, \mathrm{L}}-g_{\mathrm{m}}$ models (Eq. (4)). However, we recognize that using only data of pot-grown Platycladus orientalis saplings acclimated in growth chambers, with relatively similar canopy components (canopy structure, light interception), is not convincing enough for a general verification of the developed modeling approach. It is therefore important to collect data of more plant species to further examine the model. In addition, the $\mathrm{WUE}_{\mathrm{s}, \mathrm{P}}$ model should still be explored and 
481

improved, especially for field-grown plants with a complex canopy structure.

\section{Conclusions}

In this study, the performances of coupled $P_{\mathrm{n}, \mathrm{L}}-g_{\mathrm{sw}}$ and $P_{\mathrm{n}, \mathrm{L}}-g_{\mathrm{m}}$ models were evaluated using leaf gas exchange measurements. We found the coupled $P_{\mathrm{n}, \mathrm{L}}-g_{\mathrm{sw}}$ model incorporating the water stress-dependent function with well parameterized $q_{\mathrm{s}}$ (Eq. (2)) agreed slightly better with the measured $g_{\mathrm{sw}}$ values than the model excluding the soil water stress effect (Eq. (1)), and the established coupled $P_{\mathrm{n}, \mathrm{L}}-g_{\mathrm{m}}$ model with well parameterized $q_{\mathrm{m}}$ (Eq. (4)) allowed for a more reliable estimation of $g_{\mathrm{m}}$ than the previously introduced $g_{\mathrm{m}, \mathrm{p}^{-}}$and SWC-dependent model (Eq. (3)). Based on the well characterized models describing stomatal and mesophyll behavior, an isotopic model, scaling from leaf to whole-plant level for estimating $\mathrm{WUE}_{\mathrm{s}, \mathrm{P}}$ (Eq. (16)), was then established and validated using a combination of datasets of the leaf and the whole-plant level. The measured $\mathrm{WUE}_{\mathrm{s}, \mathrm{P}}$ was sensitive to environmental conditions, and the developed model for $\mathrm{WUE}_{\mathrm{s}, \mathrm{P}}$ proved effective at capturing response patterns to $C_{\mathrm{a}}$ and SWC. Therefore, introducing the model performing well for $g_{\mathrm{sw}}$ and $g_{\mathrm{m}}$ into the Farquhar et al. (1989) model was applicable and represents a promising approach for describing whole-plant WUE at smaller temporal scales.

\section{Acknowledgements}

This study was supported by the National Natural Science Foundation of China (No.41430747, 41401013), and the Beijing Municipal Education Commission (CEFF-PXM2018_014207_000043).

\section{Author Contributions Statement}

Yonge Zhang designed and performed the experiment. Yonge Zhang analyzed the data and wrote the manuscript. Guodong Jia and Lihua Chen contributed significantly to data analysis, manuscript preparation and practice of experiment. Xinxiao Yu revised the paper and finished the submission.

\section{References}


503 [1] Ball, J. T., Woodrow, I. E., Berry, J. A. A model predicting stomatal conductance and its contribution to the control of photosynthesis under different environmental conditions. In: Progress in photosynthesis research. Martinus Nijhoff Publishers, Netherlands (1987).

506 [2] Bögelein, R., Hassdenteufel, M., Thomas, F. M., Werner, W. Comparison of leaf gas exchange and stable isotope signature of water-soluble compounds along canopy gradients of co-occurring Douglas-fir and European beech. Plant Cell and Environment 357: 1245-1257 (2012).

[3] Collatz, G. J., Ball J, T., Grivet, C., Berry, J. A. Physiological and environmental regulation of stomatal conductance, photosynthesis and transpiration: a model that includes a laminar boundary layer. Agricultural \& Forest Meteorology 54: 107-136 (1991).

[4] Douthe, C., Dreyer, E., Brendel, O., Charles, R. W. Is mesophyll conductance to $\mathrm{CO}_{2}$ in leaves of three Eucalyptus species sensitive to short-term changes of irradiance under ambient as well as low $\mathrm{O}_{2}$ ? Functional Plant Biology 38: 434-447 (2012).

[5] Egea, G., Verhoef, A., Vidale, P. L. Towards an improved and more flexible representation of water stress in coupled photosynthesis-stomatal conductance models. Agricultural and Forest Meteorology 151(10): 1370-1384 (2011).

[6] Egea, G., Verhoef, A., González-Real, M. M., Baille, A., Nortes, P. A., \& Domingo, R. Comparison of several approaches to modelling stomatal conductance in well-watered and drought-stressed almond trees. Acta Horticulturae 922: 285-293 (2011).

[7] Escalona, J. M., Fuentes, S., Tomás, M., et al. Responses of leaf night transpiration to drought stress in Vitis vinifera L. Agricultural Water Management 118(Complete):50-58 (2013).

[8] Ethier G. J., Livingston, N. J., Harrison, D. L., Black, T. A. \& Moran, J. A Low stomatal and internal conductance to $\mathrm{CO}_{2}$ versus Rubisco deactivation as determinants of the photosynthetic decline of ageing evergreen leaves. Plant Cell and Environment 29, 2168-2184 (2006).

[9] Farquhar, G. D., Ehleringer, J. R., Hubick, K. T. Carbon isotope discrimination and photosynthesis. 
[10] Farquhar, G. D., Richards, R. A. Isotopic composition of plant carbon correlates with water-use efficiency in wheat genotypes. Australian Journal of Plant Physiology 11: 539-552 (1984).

[11] Flexas, J., Diaz-Espejo, A., Galmés, J., Kaldenhoff, R., Medrano, H., Ribas-Carbo, M. Rapid variations of mesophyll conductance in response to changes in $\mathrm{CO}_{2}$ concentration around leaves. Plant Cell and Environment 30(10):1284-1298 (2007).

[12] Flexas, J., Ribas-Carbó, M., Bota, J., Galmés, J., Henkle, M., Martínez-Cañellas, S., Medrano, H. Decreased Rubisco activity during water stress is not induced by decreased relative water content but related to conditions of low stomatal conductance and chloroplast $\mathrm{CO}_{2}$ concentration. New Phytologist 172: 73-82 (2006).

[13] Galmés, J., Medrano, H., Flexas, J. Photosynthetic limitations in response to water stress and recovery in Mediterranean plants with different growth forms. New Phytologyst 175: 81-93 (2007).

[14] Gessler, A., Rennenberg, H., Keitel, C. Stable isotope composition of organic compounds transported in the phloem of European beech-evaluation of different methods of phloem sap collection and assessment of gradients in carbon isotope composition during leaf-to-stem transport. Plant Biology 6: 721-729 (2004).

[15] Grassi, G., Magnani, F. Stomatal, mesophyll conductance and biochemical limitations to photosynthesis as affected by drought and leaf ontogeny in ash and oak trees. Plant Cell and Environment 28, 834-849 (2005).

[16] Hu, J., Moore, D. J. P., Monson, R. K. Weather and climate controls over the seasonal carbon isotope dynamics of sugars from subalpine forest trees. Plant Cell and Environment 33: 35-47 (2009).

[17] Hu, J., Moore, D. J. P., Riverosiregui, D. A., Burns, S. P., Monson, R. K. Modeling whole-tree 
carbon assimilation rate using observed transpiration rates and needle sugar carbon isotope ratios. New Phytologist 1854: 1000-1015 (2010).

551

[18] Hubick, K. T., Farquhar, G. D. Carbon isotope discrimination and the ratio of carbon gained to water lost in barley cultivars. Plant Cell and Environment 12: 795 -804 (1989).

[19] Jarvis, P. G. The interpretation of the variations in leaf water potential and stomatal conductance found incCanopies in the field. Philosophical Transactions of the Royal Society B Biological Sciences 273: 593-610 (1976).

[20] Jasoni, R., Kane, C., Green, C., Peffley, E., Tissue, D., Thompson, L., Payton, P., Paré, P. W. Altered leaf and root emissions from onion (Allium cepa L.) grown under elevated $\mathrm{CO}_{2}$ conditions. Environmental and Experimental Botany 513: 273-280 (2005).

[21] Jones, H. G. Plants and Microclimate, 2nd ed. Cambridge University Press, New York, pp 163-214 (1992).

[22] Keenan, T., Sabate, S., Gracia, C. Soil water stress and coupled photosynthesis conductance models: Bridging the gap between conflicting reports on the relative roles of stomatal, mesophyll conductance and biochemical limitations to photosynthesis. Agricultural and Forest Meteorology 150, 443-453(2010).

[23] Kodama, N., Barnard, R. L., Salmon, Y., Weston, C., Ferrio, J. P., Holst, J., Werner, R. A., Saurer, M., Rennenberg, H., Buchmann, N. Temporal dynamics of the carbon isotope composition in a Pinus sylvestris stand: from newly assimilated organic carbon to respired carbon dioxide. Oecologia 156: $737-750$ (2008).

[24] Lauteri, M., Scartazza, A., Guido, M. C., et al. Genetic variation in photosynthetic capacity, carbon isotope discrimination and mesophyll conductance in provenances of Castanea sativa adapted to different environments . Functional Ecology 11(6):675-683 (1997). 
[25] Leuning, R. A. critical appraisal of a combined stomatal-photosynthesis model for $\mathrm{C}_{3}$ plants. Plant Cell and Environment 18, 339-355 (1995).

[26] Leuning, R. Modelling Stomatal Behaviour and and Photosynthesis of Eucalyptus grandis. Functutional Plant Biology 17, 159-175 (1990).

[27] Lloyd, J. Modelling Stomatal Responses to Environment in Macadamia integrifolia. Functutional Plant Biology 18: 649-660 (1991).

[28] Lohammar, T., Larsson, S., Linder, S., Falk, S. O. FAST: Simulation Models of Gaseous Exchange in Scots Pine. Ecological Bulletins 32: 505-523 (1980).

[29] Medrano, H., Tomás, M., Martorell, S., Flexas, J., Hernández, E., Rosselló, J., Pou, A., Escalona, J., Bota, J. From leaf to whole-plant water use efficiency WUE in complex canopies: Limitations of leaf WUE as a selection target. The Crop Journal 33: 220-228 (2015).

[30] Misson, L., Limousin, J. M., Rodriguez, R., et al. Leaf physiological responses to extreme droughts in Mediterranean Quercus ilex forest. Plant Cell and Environment 33(11):1898-1910 (2010).

[31] Ohsumi, A., Hamasaki, A., Nakagawa, H., Yoshida, H., Shiraiwa, T., Horie, T. A model explaining genotypic and ontogenetic variation of leaf photosynthetic rate in rice (Oryza sativa) based on leaf nitrogen content and stomatal conductance. Annuals of Botany 99: 265-273 (2007).

[32] Perez-Martin, A., Flexas, J., Ribas-Carbó, M., et al. Interactive effects of soil water deficit and air vapour pressure deficit on mesophyll conductance to $\mathrm{CO}_{2}$ in Vitis vinifera and Olea europaea. Journal of Experimental Botany 60: 2391-2405 (2009).

[33] Pons, T. L., Flexas, J., Caemmerer, S., et al. Estimating mesophyll conductance to $\mathrm{CO}_{2}$, methodology potential errors and recommendations. Journal of Experimental Botany 608: 22172234 (2009).

[34] Porporato, A., Laio, F., Ridolfi, L., Rodriguez-Iturbe, I. Plants in water-controlled ecosystems: active role in hydrologic processes and response to water stress III. Vegetation water stress. Advance Water Resource 24: 725-744 (2001). 
597

[35] Sala, A., Tenhunen, J. D. Simulations of canopy net photosynthesis and transpiration in Quercus ilex L under the influence of seasonal drought. Agricultural and Forest Meteorology 78: 203-222 (1996).

[36] Seibt, U., Rajabi, A., Griffiths, H., Berry, J. A. Carbon isotopes and water-use efficiency, sense and sensitivity. Oecologia 155: 441-454 (2008).

[37] Tcherkez, G., Cornic, G., Bligny, R., Gout, E., Ghashghaie, J. In vivo respiratory metabolism of illuminated leaves. Plant Physiology 138: 1596-1606 (2005).

[38] Warren, C. R., Adams, M. A. Internal conductance does not scale with photosynthetic capacity, implications for carbon isotope discrimination and the economics of water and nitrogen use in photosynthesis. Plant Cell and Environment 29: 192-201 (2006).

[39] Wingate, L., Seibt, U., Moncrieff, J. B., Jarvis, P. G., Lloyd, J. J. Variations in ${ }^{13}$ C discrimination during $\mathrm{CO}_{2}$ exchange by Picea sitchensis branches in the field. Plant Cell and Environment 30: $600-616(2007)$

[40] Xu, Z., Zhou, G. Responses of photosynthetic capacity to soil moisture gradient in perennial rhizome grass and perennial bunchgrass. BMC Plant Biology 11(1): 21 (2011).

[41] Yu, G. R., Zhuang, J., Yu, Z. L. An attempt to establish a synthetic model of photosynthesistranspiration based on stomatal behavior for maize and soybean plants grown in field. Plant Physiology 158: 861-874 (2001).

[42] Zhang, Y. E., Wang, D. D., Liu, Z. Q., Jia, G. D., Yu, X. X., Chen, L. H. Whole-plant instantaneous and short-term water-use efficiency in response to soil water content and $\mathrm{CO}_{2}$ concentration. Plant and Soil 444(1-2): 281-298 (2019).

[43] Zhao, N., Meng, P., He, Y. B., Yu, X. X. Interaction of $\mathrm{CO}_{2}$ concentrations and water stress in semiarid plants causes diverging response in instantaneous win instantaneous water use efficiency 
621 